\title{
"I still find James enthralling": An Interview with Professor Rosella Mamoli Zorzi
}

DOI: http://dx.doi.org/10.12775/LC.2017.018

Mirosława Buchholtz: Professor Mamoli, the scope of your studies in literature and culture, as reflected in your numerous publications, including books and articles on American literature, is very wide. And yet, Henry James seems to have a special place in your research. What makes him special? When did you first become interested in James?

Professor Rosella Mamoli Zorzi: Yes, Henry James definitely has a special place in my research, even if I did not start out as a James scholar. I first became interested in Henry James as a student and reader, and then again in the early 1980s, when I was told there was an unpublished diary in the Biblioteca Nazionale Marciana, mentioning English and American authors, the diarist being unknown. It soon turned out it was the diary of the Curtisses, whose salon, in the magnificent Palazzo Barbaro on the Grand Canal, was a meeting point for artists, including Robert Browning and Henry James, who stayed with the Curtisses several times from 1887, and immortalized their palace in the Palazzo Leporelli in The Wings of the Dove. Once you start looking at James and Venice, at his reactions to the city and to such great painters as Titian, Tintoretto, Veronese, you are enthralled by his writings. I am now working, with a younger colleague, Simone Francescato, on a volume of stories for the Cambridge University Press critical edition of James's works, containing The Aspern Papers, and still find James enthralling.

In your publications you draw a wide panorama of James's world, tracing his acquaintance or friendship with many other Americans, for example, Isabella Stewart Gardner, Edith Wharton, or John Singer Sargent. What they all shared seems to be fascination with Europe and especially Italy.

Once you start looking at James's relationship with Italy, and with Venice, it is almost unavoidable to widen your research to Isabella Stewart Gardner, who rented the Palazzo Barbaro from the Curtisses when they were in India or in England, to Sargent, who was so much admired by James, and painted so many wonderful pictures of Venice, to Wharton, whose admiration for Venetian painters such as Tiepolo was ahead of her times. 
Which was James's favorite Italian city?

One could imagine it was Rome, before the 1880s, where in 1869 he felt he was finally "living," or Florence, or Venice, but I am not sure. In Europe there is no doubt his city was London, as much as he did love Paris, London and later Lamb House were the places where he could write, which was James's main interest throughout his life.

Several of James's major texts (at least some chapters) are set in Italy. How do you feel about such settings? Are they always realistic? Is James perhaps occasionally modifying authentic Italian settings to suit his own narrative aims?

Maybe I can reply for Venice: like every writer, James was conditioned in his perception of Venice by his readings - especially Ruskin - and by the paintings and etchings representing the city, but at the same time he perceived the poverty of the city in the second half of the nineteenth century. So one can see a romantic reading of Venice together with the sense of reality in observing its poverty. In his early tales, the characters who approach Italy through the Alps are very much entering it like Goethe, i.e. looking for the land where the "Zitronen blühn," the South, with all of its myths of beauty, warmth, and romanticism.

Among James's travel books there is a collection of travel essays entitled Italian Hours (1909). I remember meeting in the last decade of the twentieth century in France American professors (in the field of physics) who were using James's Little Tour in France (1884) as a guidebook over a century after its publication. Could it be pure nostalgia? Could Italian Hours be used as a guidebook in Italy today?

Italian Hours could certainly be used as a very special guidebook even now, although the traveller would find many things changed, many paintings with different attributions, many picturesque places completely changed.

One of James's close friends in Italy was the sculptor Hendrik Andersen. The publication in 2004 of your groundbreaking edition of James's letters to him, Beloved Boy: Letters to Hendrik C. Andersen, 1899-1915 (Charlottesville: University of Virginia Press) opened a new chapter in the study of James's biography and literary art. The book was first published in Italian in 2000. How did you become interested in these letters? Where did you find them? What were the main challenges of this project? I was lucky enough to cooperate with the director of the Rome Andersen Museum, Dr. Elena di Majo, who wanted to re-launch the museum, and asked me for help. In the museum there were typewritten copies of James's letters to Andersen: the typescripts had been prepared by Andersen himself, and were in fact very bad transcriptions. I had to check them with the original letters at the University of Virginia in order to have a correct text. Of course the great challenge was to see the relationship between James and the beautiful young sculptor: gay studies have underlined James's homosexuality, but I still think that if the very affectionate language in the letters (to be found also in James's letters to his brother William) does show James's love for the young man, it doesn't "prove" anything. 


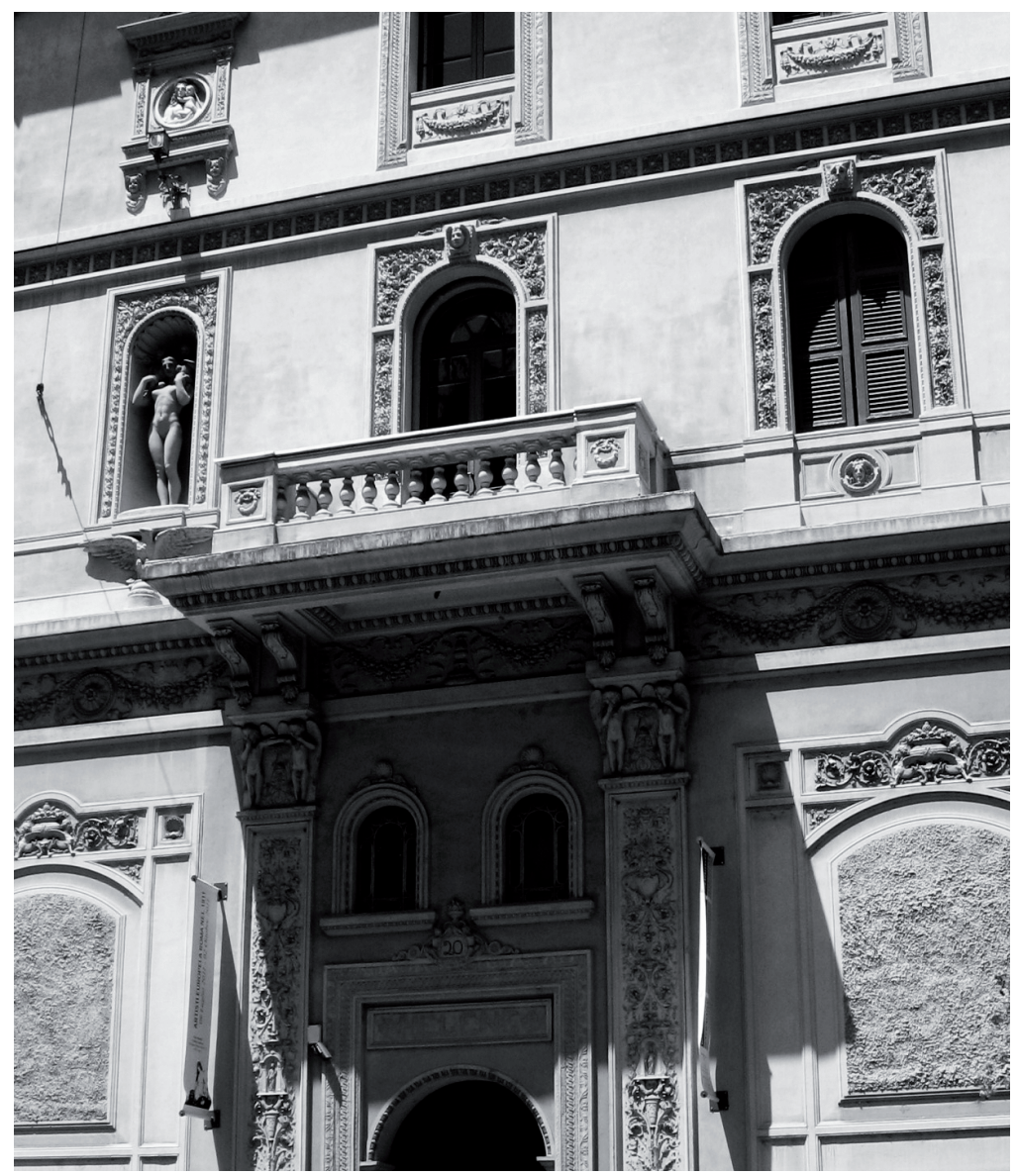

Hendrik C. Andersen Museum in Rome. Photo by Mirosława Buchholtz

I remember looking for the archives holding James's letters in Rome, out of curiosity. The doors were all closed, but I visited the Museum of Mario Praz and the Napoleonic Museum in the same building (Palazzo Primoli) instead and was very happy to sense the presence of James in those places. Was that intuition perhaps at least to some extent correct?

Yes, it was correct, in the sense that Primoli, highly valued also as a photographer, knew James.

In 2000 the Hendrik C. Andersen Museum was opened in Rome. In what ways is it a museum of Henry James?

I think Andersen's statues deserved all the terrible and negative comments which James made, in spite of his love for the young sculptor. James's evaluation of art was never influenced by his friendship with the authors. The director di Majo had the wonderful idea of placing in the museum an installation (2001) by Yinka Shonibare, a marvellous Nigerian artist who made two images of Andersen and James, fronting each other (without their heads), wearing perfectly Victorian clothes made, however, in bright African prints. 
Ezra Pound also belongs to the long list of American authors whose works and Italian travel you have researched and published on. What might be the links between Pound and James?

Ezra Pound's attitude to James seems to me that of a pupil to a master. In his introduction to Indiscretions; or, Une Revue de Deux Mondes (1923), Pound wrote that he was taking up the analysis of American moeurs from the point where James had left it in "The Middle Years."

\section{Thank you for the interview!}

Interview by Mirosława Buchholtz*

* Professor of English and Director of the English Department at Nicolaus Copernicus University in Toruń, where she teaches American and Canadian literature. Her research interests include also film adaptations of literature, life writing, and postcolonial studies. E-mail: Miroslawa.Buchholtz@umk.pl. 